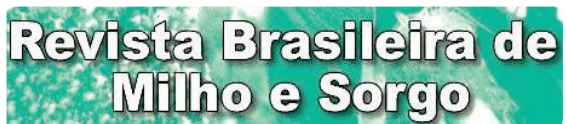

Brazilian Journal of Maize and Sorghum

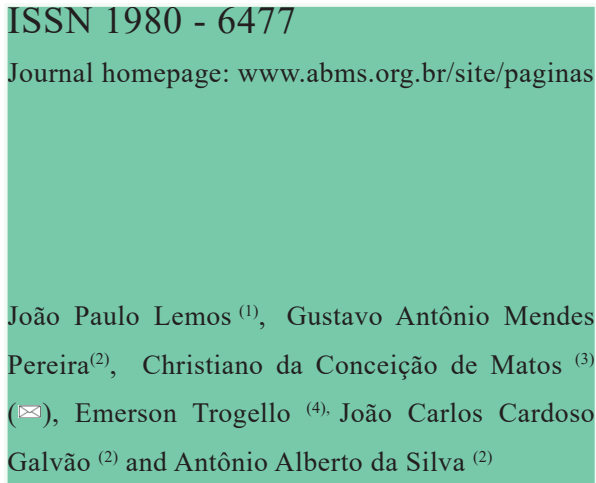

Instituto Federal de Educação Ciência Tecnologia de Minas Gerais

E-mail: joao.lemos@ifmg.edu.br

(2) Universidade Federal de Viçosa

E-mail: gustavogamp@hotmail.com,

jgalvao@ufv.br,

aasilva@ufv.br.

Universidade do Estado de Minas Gerais

Unidade de Ituiutaba

E-mail: christiano.matos@uemg.br

Instituto Federal Goiano

E-mail: emerson.trogello@ifgoiano.edu.br

Corresponding author

How to cite

LEMOS, J. P.; PEREIRA, G. A. M.; MATOS, C C.; TROGEllo, E.; GAlVÃO, J. C. C.; SILVA A. A. Physiological response of conventional and transgenic maize to water stress. Revista Brasileira de Milho e Sorgo, v. 19, e1144, 2020.

\section{PHYSIOLOGICAL \\ RESPONSE OF CONVENTIONAL AND TRANSGENIC MAIZE TO WATER STRESS}

\begin{abstract}
Genetic modifications of plants can affect their ability to use environmental resources. It is known that the anthropic action has caused global climate changes, such as increases in temperature and drought. In view of this, the objective of this study was to evaluate if the addition of the Bt gene influences the physiological performance of isogenic maize hybrids grown under water stress and optimal conditions. Three Bt and non-Bt maize hybrids (Agromen 30A95, Dow 2B707 and BG 7049Y) were cultivated in soil with moisture content at $60 \%$ (water stress) and $100 \%$ of the field capacity (FC). Among the hybrids, the $30 \mathrm{~A} 95$ presented greater variation between $B t$ and non-Bt hybrids in regard to physiological variables. The addition of the $B t$ gene practically had no impact on the photosynthetic performance of the 2B707 and BG7049 hybrids. The presence of the $B t$ gene increased the sensitivity to water stress in the hybrids, with reduction of maximal fluorescence and chlorophyll content in the plants. Regardless of the genetic factor ( $B t$ or non-Bt), water stress reduced transpiration, stomatal conductance, photosynthetic rate, and maximum quantum yield of the PSII in maize plants. It was concluded that the presence of the $B t$ gene in maize indicates a reduction in the photosynthetic potential of the plant grown under water stress.

Keywords: Zea mays, Bacillus thuringiensis, chlorophyll fluorescence, genetic modification

\section{RESPOSTA FISIOLÓGICA DE MILHO CONVENCIONAL E TRANSGÊNICO AO ESTRESSE HÍDRICO}

\begin{abstract}
Resumo - Modificações genéticas de plantas podem afetar a capacidade das mesmas em utilizar os recursos do ambiente. É conhecido que a ação antrópica tem causado mudanças climáticas globais, tais como aumentos de temperatura e seca. Diante disso, o objetivo desse estudo foi o de avaliar se a adição do gene $B t$ influencia o desempenho fisiológico de híbridos isogênicos de milho, cultivados em condições ótimas e em estresse hídrico. Três híbridos de milho Bt e não-Bt (Agromen 30A95, Dow 2B707 e BG 7049Y) foram cultivados em solo com umidade de 60 $\%$ (estresse hídrico) e $100 \%$ da capacidade de campo (CC). Entre os híbridos, o 30A95 apresentou maior variação nas variáveis fisiológicas entre os híbridos $B t$ e não- $B t$. A adição do gene $B t$ praticamente não influenciou o desempenho fotossintético dos híbridos 2B707 e BG7049. A presença do gene Bt aumentou a sensibilidade dos híbridos ao estresse hídrico reduzindo a fluorescência máxima e o teor de clorofilas das plantas. Independente do fator genético ( $B t$ ou não-Bt), o estresse hídrico reduziu a transpiração, condutância estomática, taxa fotossintética e o rendimento quântico máximo do PSII do milho. Conclui-se que a presença do gene $B t$ no milho sugere uma redução no potencial fotossintético da cultura submetida ao estresse hídrico.
\end{abstract}

Palavras-chave: Zea mays, Bacillus thuringiensis, fluorescência da clorofila, modificação genética 
The biotechnology provides means to increase the agricultural production by applying the molecular knowledge related to gene function and regulatory networks involved in stress tolerance, development and growth of plants (Atanassova \& Keiper, 2018). The new cultivars available in the market present high genetic potential, in addition to other advantages related to phytosanitary and physiological aspects, being capable of providing high yield (Brookes \& Barfoot, 2018; Nuccio et al., 2018). A highly employed technology is the modification of plants to express insecticidal proteins from Bacillus thuringiensis (known as Bt plants), which provides insect resistance to the varieties that have gone through that process, such as maize, cotton, rice, etc. (Kamthan et al., 2016; Pellegrino et al., 2018). This technology has been widely accepted, with successive increase of the areas with transgenic plant crops, such as the $B t$ maize, in many countries (Xing et al., 2019).

However, genetic modifications of plants for certain purposes, such as the induction of resistance to insects, pathogens, herbicides, and others, can affect their capacity to use natural resources, such as water, $\mathrm{CO}_{2}$, light and nutrients (Balieiro Neto et al., 2013). The Bt cotton, for example, presents a more vigorous nitrogen metabolism in the vegetative stage than its non$B t$ version (Chen et al., 2004), while conventional soybean plants have more chlorophyll content than their transgenic versions (Caires et al., 2010).

The anthropic activities have accelerated global warming and caused several climate changes, such as rise in temperature, increase in the frequency and severity of climate events (such as heat waves and droughts), and changes in precipitation patterns (Jamieson et al., 2012). Drought is one of the biggest challenges for agricultural activities worldwide (Rolli et al., 2015). In view of this scenario, and considering the increase of transgenic plant crops, it is important to know if the process used to obtain those plants influences their capacity to tolerate water deficit. The transgenic hybrids used in this research presented regular phenotypes, with no visible differences as to growth or morphological characteristics.

Besides the changes expected as a result of genetic transformation, some studies identified alterations in transgenic maize plants, such as modifications in the stem diameter, leaf area, interval between male and female flowering, and antioxidant enzyme content (Rasco Jr et al., 2010). This reinforces the hypothesis that physiological and morphological changes may occur in transgenic maize plants when compared to the conventional versions. In view of this, the objective of this study was to confirm if the addition of the $B t$ gene influences the performance of isogenic maize cultivars grown under optimal conditions and water stress.

\section{Material and Methods}

The experiment was carried out in a greenhouse of the Department of Agronomy at 
the Federal University of Viçosa, from March to June 2013, in randomized block design with a $3 \times 2 \times 2$ factorial arrangement, and five replications. The first factor consisted of three maize hybrids. The second factor corresponded to two types of each of the hybrids used: transgenic with Bt event [AGROMEN 30A95Hx (TC 1507), DOW 2B707Hx (TC 1507), and BG 7049Y (MON 810)], being the first two Herculex I ${ }^{\circledR}$ hybrids and the third a YieldGard ${ }^{\circledR}$ hybrid; and conventional hybrids (AGROMEN 30A95, DOW 2B707, and BG 7049). The third factor was the presence or not of water deficit $(60 \%$ and $100 \%$ of the field capacity). During the plant growth period, the minimum and maximum temperatures in the greenhouse were, on average, $16.5{ }^{\circ} \mathrm{C}$ and $32.5{ }^{\circ} \mathrm{C}$, respectively, while the relative humidity remained close to $85 \%$.

The substrate used for plant cultivation consisted of samples of Red-Yellow Latosol with $75 \%$ clay (Table 1). Pots with $30.0 \mathrm{dm}^{-3}$ capacity (height $=40 \mathrm{~cm}$, top diameter $=33 \mathrm{~cm}$, and bottom diameter $=29 \mathrm{~cm}$ ) were filled with air-dried soil samples, pounded to break up clods and sieved through a $20-\mathrm{mm}$ mesh sieve. For $\mathrm{pH}$ correction, $0.045 \mathrm{~kg}$ of dolomitic limestone was mixed with the soil in each pot $\left(3.0 \mathrm{t} \mathrm{ha}^{-1}\right)$. Subsequently, the pots remained incubated for 60 days, with soil moisture content at $60 \%$ of the field capacity (FC).

Pre-planting fertilization was done by adding $160 \mathrm{mg} \mathrm{dm}^{-3}$ of $\mathrm{P}_{2} \mathrm{O}_{5}$ and $75 \mathrm{mg} \mathrm{dm}^{-3}$ of $\mathrm{K}_{2} \mathrm{O}$ to the soil. Single superphosphate and potassium chloride were used as sources of $\mathrm{P}$ and $\mathrm{K}$, respectively. Soil from each pot was placed inside a raffia bag and the fertilizers were then incorporated by shaking the soil-fertilizer mixture. In addition, the 20-0-20 formulated fertilizer was applied on soil surface $\left(3 \mathrm{~g} \mathrm{pot}^{-1}\right)$ and, subsequently, irrigation was done to mantain the soil at field capacity.

Water deficit was calculated according to the soil water retention curve. Retention data were interpolated through the Van Genuchten equation (Eq. 1), which describes the behavior of soil moisture content as a function of soil moisture tension.

$$
\theta v=\theta r+\frac{\theta s-\theta r}{\left[1+(a|\Psi m|)^{n}\right]^{m}}
$$

Where: $\theta v=$ volumetric water content in $\mathrm{cm}^{3} \mathrm{~cm}^{-3} ; \theta \mathrm{r}=$ residual water content in $\mathrm{cm}^{3}$ $\mathrm{cm}^{-3} ; \quad \theta \mathrm{s}=$ saturated water content in $\mathrm{cm}^{3}$ $\mathrm{cm}^{-3} ; \Psi \mathrm{m}=$ matric potential in $\mathrm{cm}$; and $\alpha, \mathrm{m}, \mathrm{n}$ are model parameters.

The behavior of the water content in the studied soil as a function of tension was as follows (Eq. 2):

$$
\theta v=0.163+\frac{0.387}{\left[1+(1.3378|\Psi m|)^{2.9209}\right]^{0.1441}}
$$

For maize planting, three maize seeds were sowed per pot. After seedling emergence, one maize plant was kept in each pot. Micronutrient fertilizer was surface applied 17 days after emergence (DAE), containing $1.39 \mathrm{mg} \mathrm{dm}^{-3}$ of 
Table 1. Physical and chemical characteristics of Red-Yellow Latosol used in the experiment, before correction and planting fertilization.

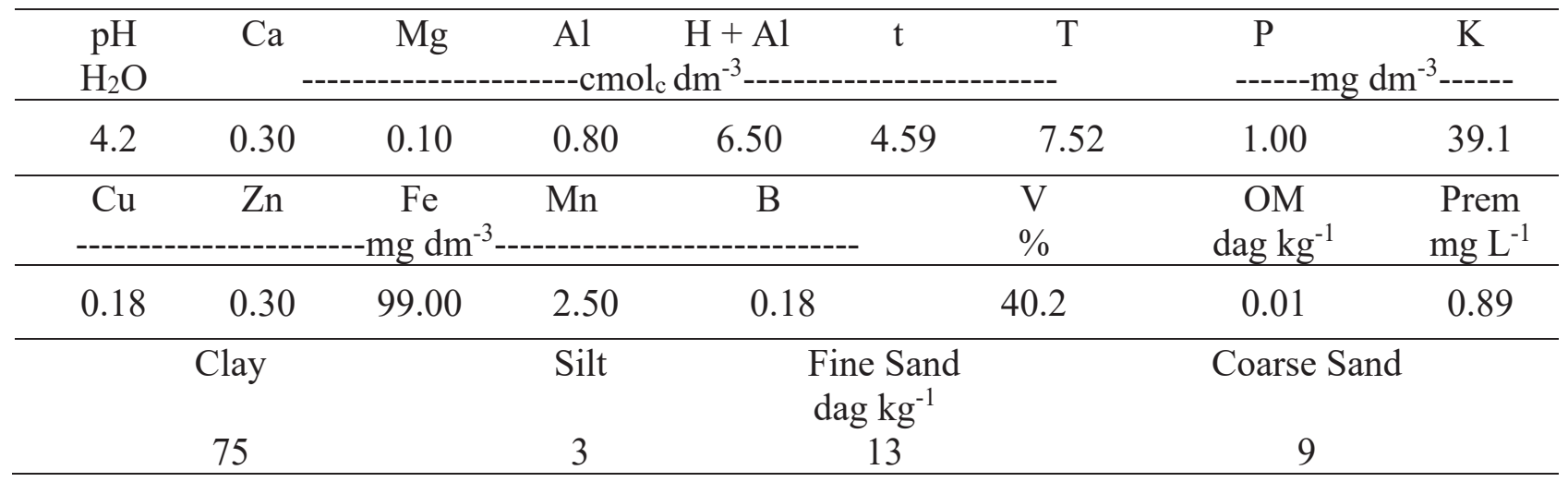

$\mathrm{pH}$ in water; $\mathrm{Ca}, \mathrm{Mg}$ and $\mathrm{Al}, \mathrm{KCl}$ extractor $1 \mathrm{~mol} \mathrm{~L}^{-1}$; $\mathrm{Ca}(\mathrm{OAc})^{2} 0.5 \mathrm{~mol} \mathrm{~L}^{-1} \mathrm{pH} 7.0-\mathrm{H}+\mathrm{Al} ; \mathrm{P}, \mathrm{K}, \mathrm{Cu}, \mathrm{Zn}, \mathrm{Fe}, \mathrm{Mn}$, Mehlich-1 extractor; B, hot water; V, base saturation index; m, aluminum saturation index; OM, organic matter; Prem, $P$ remaining.

boric acid; $2.61 \mathrm{mg} \mathrm{dm}^{-3}$ of copper chloride, $2.03 \mathrm{mg} \mathrm{dm}^{-3}$ of zinc chloride, and $0.36 \mathrm{mg} \mathrm{dm}^{-3}$ of molybdic acid.

Soil moisture was monitored with the use of T5 Miniature Tensiometer (INFIELD 5) with sensitivity of $0.1 \mathrm{kPa}$. The tensiometer shaft was installed in a position perpendicular to the soil surface, with measurement done in a $10 \mathrm{~cm}$ depth range. Readings were taken every 24 hours and the applied water volume was calculated based on the soil water retention curve (Eq. 3). The soil matric potential at field capacity was $-10 \mathrm{kPa}$, while in the water deficit treatment $(60 \%$ of the field capacity), it was $-70 \mathrm{kPa}$.

$$
V=(\theta f c-\theta \text { Actual }) \times 19,000
$$

Where: $\mathrm{V}=$ water volume in $\mathrm{cm}^{3} ; \theta_{\mathrm{fc}}=$ water content at field capacity in $\mathrm{cm}^{3} \mathrm{~cm}^{-3} ; \theta_{\text {Actual }}=$ moisture tension in each treatment in $\mathrm{cm}^{3} \mathrm{~cm}^{-3}$; and $19,000=$ soil volume in the pot in $\mathrm{cm}^{3}$.

The water stress treatment was applied for 21 days, during the V5 stage (five fully expanded leaves) up to the V9 stage (nine fully expanded leaves) of maize plants.

Physiological measurements were made 41 DAE. On that occasion, the maize plants presented nine fully expanded leaves (V9). Data were collected from 8 to 10 a.m. During the measurements, the temperature varied from 16 to $28{ }^{\circ} \mathrm{C}$ and the relative humidity varied from 65 to $85 \%$.

Chlorophyll fluorescence $(a)$ was obtained with the use of the OS5p Multi-Mode Chlorophyll Fluorometer (Opti-Sciences). Analyses were conducted by evaluating the chlorophyll fluorescence emission on the adaxial leaf surface.

After a dark adaptation period of 30 minutes, and under controlled temperature $\left(26^{\circ} \mathrm{C}\right)$, the minimal fluorescence $(\mathrm{Fo})$ was 
measured under sufficiently low light, as well as the maximal fluorescence $(\mathrm{Fm})$, with application of a saturating light pulse of $7,000 \mu \mathrm{m}$ photons $\mathrm{m}^{-2} \mathrm{~s}^{-2}$ for 0.8 second. The following were obtained from the dark-adapted samples: variable fluorescence, $F v=(F m-F o)$; maximum efficiency of photosystem (PSII) or maximum quantum yield (potential) of the PSII $\left(F_{v} / F_{m}\right)$; maximum quantum efficiency of the photochemical process in the PSII $\left(F_{v} / F_{\mathrm{o}}\right)$; and basal quantum yield of non-photochemical processes in the PSII, calculated by the $F_{o} / F_{m}$ ratio (Roháček, 2002).

Once the parameters were determined in the dark-adapted state, the leaves were submitted to a saturating light pulse with intensity of $1,500 \mu \mathrm{mol}$ photons $\mathrm{m}^{-2} \mathrm{~s}^{-1}$ and duration of 15 seconds, in order to determine the following parameters of the light-adapted state: Fms - maximal fluorescence; photochemical quenching calculated as $q P=(F m s-$ $\mathrm{Fs}) /\left(F m s-F o^{\prime}\right)$; and non-photochemical quenching, or non-photochemical dissipation, calculated as $\mathrm{NPQ}=(F m-F m s) / F m s$. Other parameters obtained were: electron transport rate $(\mathrm{ETR})=[(F m s-F s /$ $F m s) \times$ PPFD x $0.5 \times 0.84$, which corresponds to (quantum yield of the PSII) $x$ (measure of photosynthetically active radiation in $\mu \mathrm{Mol}$ electrons $\mathrm{m}^{-2} \mathrm{~s}^{-1}$ ) $\mathrm{x}$ (leaf absorption coefficient) $x$ (fraction of light absorbed by the antenna complex of the PSII), being a measurement of charge separation at the PSII reaction center; and the effective quantum yield of the PSII in lightadapted state (PSII): $\mathrm{Y}=F m \mathrm{~s}-F / F m \mathrm{~s}=\Delta \mathrm{F} / F m$ ' (van Kooten \& Snel, 1990).

The chlorophyll content was measured with the use of the chlorophyll meter Minolta SPAD-502 (Soil Plant Analysis Development). The fully developed youngest leaf of each plant was selected. Readings were taken at leaf base, center and apex, with the chlorophyll content value representing the average of those three measures. On the same leaf, measurements were made using LI-6400 Infrared Gas Analyser (IRGA), produced by LI-COR, by applying a luminosity factor of $1,500 \mathrm{~mol}$ photons $\mathrm{m}^{-2} \mathrm{~s}^{-1}$.

The variables obtained with IRGA were: photosynthetic rate $\left(A-\mu \mathrm{mol} \mathrm{CO}_{2} \mathrm{~m}^{-2} \mathrm{~s}^{-1}\right)$; transpiration $\left(E-\mathrm{mmol} \mathrm{H}_{2} \mathrm{O} \mathrm{m}^{-2} \mathrm{~s}^{-1}\right)$; stomatal conductance $\left(g \mathrm{~s}-\mathrm{mol} \mathrm{H}_{2} \mathrm{O} \mathrm{m} \mathrm{m}^{-2} \mathrm{~s}^{-1}\right)$; and $\mathrm{CO}_{2}$ consumed $\left(\Delta \mathrm{C}-\mu \mathrm{mol} \mathrm{CO} \mathrm{s}^{1}\right)$.

Throughout the experiment, visual observations were made of the morphophysiological parameters of maize associated with water stress, such as the leaf roll.

All data obtained were submitted to analysis of variance (Table 7) and the means were compared through Tukey's test at 5\% significance.

\section{Results and Discussion}

$F v$ values were similar in the comparisons between conventional maize hybrids or between $B t$ hybrids cultivated under water deficit condition ( $60 \%$ of FC) (Table 2). On the other hand, when maize was cultivated in soil at field capacity, $F v$ varied between conventional hybrids and between transgenic hybrids. 
Under water deficit condition, $F v$ NPQ than its isogenic version (Table 2). Those values were similar between conventional and transgenic hybrids (Table 2). When the soil was at field capacity, only the conventional 30A95 cultivar presented higher $F v$ than its isogenic version (Table 2).

When the plants were submitted to water deficit conditions, no significant differences were observed as to NPQ in the comparisons between conventional hybrids or between transgenic hybrids (Table 2). At field capacity, the NPQ of the 2B707 hybrid was higher when compared to BG 7049 (Table 2), considering only the transgenic hybrids. In addition, only the conventional 30A95 cultivar presented lower results suggest differences associated with the capacity of the isogenic cultivars to tolerate photoinhibition conditions caused by excess light energy. In general, NPQ is formed by three components: $\mathrm{NPQ}_{\mathrm{E}}$ (related to $\mathrm{H}+$ gradient across the thylakoid membrane), $\mathrm{NPQ}_{\mathrm{T}}$ (related to distribution of excitation energy between the two photosystems, regulated by phosphorylation and dephosphorylation of the reaction center), and $\mathrm{NPQ}_{\mathrm{I}}$ (related to photoinhibition of photosynthesis) (Mishra, 2018). The $\mathrm{NPQ}_{\mathrm{E}}$ was probably the main non-photochemical dissipation component (nonradiative energy dissipation) of the 30A95 Bt hybrid, since it is linearly related

Table 2. Variable fluorescence $(F v)$ and non-photochemical quenching (NPQ) in $B t$ and non- $B t$ maize hybrids cultivated in soil with moisture content at 60 and $100 \%$ of the field capacity (FC), 41 days after emergence.

\begin{tabular}{|c|c|c|c|c|c|c|c|c|}
\hline \multirow{3}{*}{ Hybrid } & \multicolumn{4}{|c|}{$F v$} & \multicolumn{4}{|c|}{ NPQ } \\
\hline & \multicolumn{2}{|l|}{$60 \% \mathrm{FC}$} & \multicolumn{2}{|l|}{$100 \%$ FC } & \multicolumn{2}{|l|}{$60 \% \mathrm{FC}$} & \multicolumn{2}{|l|}{$100 \% \mathrm{FC}$} \\
\hline & Non- $B t$ & Bt & Non- $B t$ & $B t$ & Non- $B t$ & $B t$ & Non- $B t$ & $B t$ \\
\hline Agromen 30A95 & $2379.80 \mathrm{aA}$ & $2295.60 \mathrm{aA}$ & $2878.80 \mathrm{aA}$ & $2210.20 \mathrm{bB}$ & $0.962 \mathrm{aA}$ & $1.186 \mathrm{aA}$ & $0.904 \mathrm{aB}$ & $1.345 \mathrm{abA}$ \\
\hline Dow 2B707 & $2429.00 \mathrm{aA}$ & $2394.60 \mathrm{aA}$ & $2633.80 \mathrm{abA}$ & $2696.20 \mathrm{aA}$ & $1.178 \mathrm{aA}$ & $1.355 \mathrm{aA}$ & $1.269 \mathrm{aA}$ & $1.503 \mathrm{aA}$ \\
\hline \multirow[t]{3}{*}{ BG 7049} & $2750.80 \mathrm{aA}$ & $2413.75 \mathrm{aA}$ & $2436.80 \mathrm{bA}$ & $2359.20 \mathrm{abA}$ & $1.356 \mathrm{aA}$ & $1.168 \mathrm{aA}$ & $1.108 \mathrm{aA}$ & $1.193 \mathrm{bA}$ \\
\hline & Non- $B t$ & & $B t$ & & Non- $B t$ & & $B t$ & \\
\hline & $60 \% \mathrm{FC}$ & $100 \% \mathrm{FC}$ & $60 \% \mathrm{FC}$ & $100 \% \mathrm{FC}$ & $60 \% \mathrm{FC}$ & $100 \% \mathrm{FC}$ & $60 \% \mathrm{FC}$ & $100 \% \mathrm{FC}$ \\
\hline Agromen30A95 & $2379.80 \mathrm{bA}$ & $2878.80 \mathrm{aA}$ & $2295.60 \mathrm{aA}$ & $2210.20 \mathrm{aA}$ & $0.962 \mathrm{aA}$ & $0.904 \mathrm{aA}$ & $1.186 \mathrm{aA}$ & $1.345 \mathrm{aA}$ \\
\hline Dow 2B707 & $2429.00 \mathrm{aA}$ & $2633.80 \mathrm{aA}$ & $2394.60 \mathrm{aA}$ & $2696.20 \mathrm{aA}$ & $1.178 \mathrm{aA}$ & $1.269 \mathrm{aA}$ & $1.355 \mathrm{aA}$ & $1.503 \mathrm{aA}$ \\
\hline BG 7049 & $2750.80 \mathrm{aA}$ & $2436.80 \mathrm{aA}$ & $2413.75 \mathrm{aA}$ & $2359.20 \mathrm{aA}$ & $1.356 \mathrm{aA}$ & $1.108 \mathrm{aA}$ & $1.168 \mathrm{aA}$ & $1.193 \mathrm{aA}$ \\
\hline
\end{tabular}

* Means followed by the same letter, lowercase in columns and uppercase in rows, for each variable at each water availability percentage, do not differ from one another at 5\% probability as per Tukey's test. 
to $\mathrm{H}^{+}$concentration within the chloroplast thylakoids (Ruban et al., 2012; Sato et al., 2017), being responsible for $F v$ reduction in that hybrid (Table 2).

Furthermore, the xanthophyll cycle activation may occur as a result of the high light intensity, which is involved in energy dissipation with the increase of zeaxanthin content, through the enzymatic conversion of violaxanthin or through the own increase of that pigment synthesis (Araújo \& Deminicis, 2009). In some cases, that may accelerate leaf senescence due to the higher pigment degradation caused by reactive oxygen species, whose production increases under water deficit condition (Karuppanapandian et al., 2011.

Water deficit has not affected $F v$ or NPQ of $B t$ and non- $B t$ maize hybrids (Table 2 and Table 7). Considering the soil under no water deficit condition, there was no difference of $F v$ between the conventional hybrids (Table 2). On the other hand, water deficit reduced $F v$ of the Agromen 30A95 non-Bt hybrid. Fv represents the flow of electrons from the PSII reaction center ( $\mathrm{P} 680)$ until the plastoquinone $\left(\mathrm{PQH}_{2}\right)$, that is, shows the efficiency of the energy transfer process and chloroplast activity. Therefore, the flow of electrons in the PSII indicates the global photosynthesis rate, which enables the estimation of photosynthetic performance almost instantaneously (Mishra, 2018).In practical terms, $F v$ reduction indicates loss of chloroplast function (Banks, 2017) and/or loss of chlorophyll contents (Murchie \& Lawson, 2013; Tan et al., 2019), as observed for the Agromen
30A95 hybrid (Table 4), which indicates that this conventional hybrid may have its photosynthetic capacity reduced by the soil water deficit.

Only the gene factor influenced $\mathrm{Fm}$ of maize, with the lower values observed in $B t$ hybrids (Table 3). Reduction of $F m$ in $B t$ maize hybrids, without changing $F_{0}$, may occur due to an increase in the thermal dissipation as a result of inactivation of the PSII reaction center of those plants (Bertamini \& Nedunchezhian, 2003)under controlled conditions (irradiation of detached leaves to about $1900 \mu \mathrm{E} \mathrm{m}-2 \mathrm{~s}-1$. However, this fact alone does not prevent the occurrence of damages in the PSII reaction centers. In addition, the lower absolute values of $F m$ in $B t$ hybrids may be due to the lower photoreduction capacity of the quinone $\mathrm{A}(\mathrm{Qa})$, stable primary electron acceptor of the PSII in those plants (Baker, 2008).

The hybrid factor and the interaction between gene and water availability affected the chlorophyll content (SPAD) of maize leaf (Table 7). The lowest chlorophyll content was observed in the 30A95 hybrid (Table 4). That difference is probably due to the distinct genetic nature of the maize hybrids.

Non- $B t$ hybrids presented higher chlorophyll content than those with the $B t$ gene in plants cultivated under water deficit (Table 4). Similar results were observed in isogenic cultivars of soybean, in which the water deficit caused an abrupt degradation of leaf chlorophyll in the transgenic varieties (Caires et al., 2010).

For the characteristics $F_{v} / F_{m^{\prime}} F_{o} / F_{m^{\prime}} F_{v} / F_{o}$ and $\Delta C$, the interaction of hybrid and gene was 
Table 3. Maximal fluorescence $(F m)$ in $B t$ and non-Bt maize hybrid, 41 days after emergence.

\begin{tabular}{ll}
\hline Gene & $F m$ \\
\hline Non- $B t$ & $3346.73 \mathrm{a}$ \\
$B t$ & $3133.20 \mathrm{~b}$ \\
\hline
\end{tabular}

* Means followed by the same lowercase letter in the columns do not differ from one another at $5 \%$ probability as per Tukey's test.

Table 4. Chlorophyll content (SPAD) in $B t$ and non- $B t$ maize hybrids cultivated in soil with moisture content at 60 and $100 \%$ of the field capacity (FC), 41 days after emergence.

\begin{tabular}{lll}
\hline Hybrid & & SPAD \\
\hline Agromen 30A95 & $37.125 \mathrm{~b}$ & \\
Dow 2B707 & $44.065 \mathrm{a}$ & \\
BG 7049 & $40.840 \mathrm{a}$ & \\
\hline & $60 \% \mathrm{FC}$ & $100 \% \mathrm{FC}$ \\
\hline Non- $B t$ & $41.09 \mathrm{aA}$ & $41.81 \mathrm{aA}$ \\
$B t$ & $36.94 \mathrm{bB}$ & $42.85 \mathrm{aA}$ \\
\hline
\end{tabular}

*Means followed by the same letter, lowercase in columns and uppercase in rows, do not differ from one another at $5 \%$ probability as per Tukey's test.

unfolded (Table 7) by comparing the conventional or transgenic hybrids among themselves, or analyzing conventional $\mathrm{x}$ transgenic hybrids (Table 5). The variables $F_{v} / F_{m}, F_{v} / F_{o}$ and $F_{o} /$ $F_{m}$ differed only between isogenic cultivars of the 30A95 hybrid. The conventional 30A95 hybrid presented higher $F_{v} / F_{m}$ and $F_{v} / F_{o}$ than the transgenic version (Table 5). In contrast, that same conventional hybrid presented $F_{o} / F_{m}$ lower than its transgenic version.

The $F_{v} / F_{m}$ ratio has been used to detect disturbances in the photosynthetic system caused by abiotic and biotic stresses, considering that its decrease indicates inhibition of photochemical activity (Matos et al., 2015)in the form of nutrient availability in soil, is fundamental to management of agroecosystems. This study aimed to evaluate the effect of concentrations of $\mathrm{N}, \mathrm{P}$ and $\mathrm{K}$ on the growth of $\mathrm{N}$. physalodes. The experiment was carried out in greenhouse conditions, using a randomized complete block design with split-plot arrangement $(4 \times 10$. That ratio is an estimate of the maximum quantum efficiency of the photochemical activity of the PSII (Cassana et al., 2013). Values of $F_{v} / F_{m}$ between 0.75 and 0.85 demonstrate efficient conversion of light energy at PSII level and, consequently, no damages in the photochemical 
Table 5. Maximum quantum yield $\left(F_{v} / F_{m}\right)$, basal quantum yield of non-photochemical processes in the PSII $\left(F_{o} / F_{m}\right)$, maximum efficiency of the photochemical process in the PSII $\left(F_{v} / F_{o}\right)$, and $\mathrm{CO}_{2}$ consumed $(\Delta \mathrm{C})$ in $B t$ and non-Bt maize hybrids, 41 days after emergence.

\begin{tabular}{lllllllll}
\hline \multirow{2}{*}{ Hybrid } & $F_{v} / F_{m}$ & & $F_{o} / F_{m}$ & & $F_{v} / F_{o}$ & \multicolumn{2}{c}{$\Delta C\left(\mu \mathrm{mol} \mathrm{CO}_{2} \mathrm{~s}^{-1}\right)$} \\
\cline { 2 - 9 } Agromen 30A95 & Non- $B t$ & $B t$ & Non- $B t$ & $B t$ & Non- $B t$ & $B t$ & Non- $B t$ & $B t$ \\
\cline { 2 - 9 } & $0.772 \mathrm{aA}$ & $0.753 \mathrm{aB}$ & $0.222 \mathrm{aB}$ & $0.246 \mathrm{aA}$ & $3.545 \mathrm{aA}$ & $3.074 \mathrm{aB}$ & $209.01 \mathrm{aA}$ & $234.36 \mathrm{bA}$ \\
Dow 2B707 & $0.751 \mathrm{aA}$ & $0.771 \mathrm{aA}$ & $0.243 \mathrm{aA}$ & $0.227 \mathrm{aA}$ & $3.209 \mathrm{aA}$ & $3.434 \mathrm{aA}$ & $234.26 \mathrm{aB}$ & $328.53 \mathrm{aA}$ \\
& & & & & & & & \\
BG 7049 & $0.773 \mathrm{aA}$ & $0.764 \mathrm{aA}$ & $0.222 \mathrm{aA}$ & $0.236 \mathrm{aA}$ & $3.504 \mathrm{aA}$ & $3.303 \mathrm{aA}$ & $263.10 \mathrm{aA}$ & $234.40 \mathrm{bA}$
\end{tabular}

\footnotetext{
* Means followed by the same letter, lowercase in columns and uppercase in rows, for each variable, do not differ from one another at $5 \%$ probability as per Tukey's test.
}

reactions of the plant (Abid et al., 2017; Quiles, 2005). In this work, the maize hybrids presented values of $F_{v} / F_{m}$ between 0.75 and 0.85 (Table 5), which suggests that the presence of the $B t$ gene has not caused photoinhibitory damages in maize plants.

In general, the response of plants to water deficit involves a rapid decline in the $F_{v} / F_{m}$ ratio (Baghel et al., 2018; Ju et al., 2018). The magnitude of that response varies among the plants and even within the same plant species. Sorghum plants with lower tolerance to water deficit presented higher reductions of $F_{v} / F_{m}$ in relation to the tolerant cultivars (Moreira et al., 2013). Similarly, transgenic sugarcane lines presented $F_{v} / F_{m}$ values $65 \%$ higher when compared to conventional plants under the same water deficit condition (Molinari et al., 2007). In the present research, the addition of the $B t$ gene has not influenced the $F_{v} / F_{m}$ ratio of maize cultivars under both growth conditions ( $100 \%$ and $60 \%$ of FC), which suggests that the addition of such gene may have had no effect on the plant genetic characteristics associated with water stress tolerance mechanisms.

The conventional cultivar of the 30A95 hybrid had a better physiological performance (higher $F_{v} / F_{m}$ and $F_{v} / F_{o}$, and lower $F_{o} / F_{m}$ ) than its isogenic version with the $B t$ gene (Table 5). Such differences are possibly associated with the genetic nature of that cultivar and its interaction with the $B t$ gene. Enclosed sequences inserted in transgenes in T-DNA, such as promoters, terminators or antibiotic resistance markers, may change neighbouring gene expression (Latham et al., 2006)In addition to that, mutations along the genome may occur, thus influencing the behavior of transformed plants (Latham et al., 2006).

The $F_{o} / F_{m}$ ratio indicates the basal quantum yield of the non-photochemical process in the PSII, with values between 0.14 and 0.20 being commonly attributed to plants 
in suitable physiological conditions (Roháček \& Barták, 1999). However, the increase in that ratio is a stress indication (Roháček, 2002). Water stress probably produced the increase of $F_{o} / F_{m}$ values in maize hybrids (Table 5 and Table 6). Increment in $F_{o} / F_{m}$ values due to water stress was also observed in Copaifera langsdorff seedlings (Rosa et al., 2018).

The $\mathrm{CO}_{2}$ consumed $(\Delta C)$ varied only between the transgenic hybrids, with the highest value being observed in the 2B707 maize (Table 5). This hybrid also presented higher $\Delta C$ than its conventional isogenic version (Table 5). Typically, the increase of $\Delta C$ is directly associated with higher photosynthetic rate $(A)$ and lower internal $\mathrm{CO}_{2}$ concentration in the plant leaf (Aspiazú et al., 2010), which may reflect in higher carbon assimilation and plant growth rates. However, no difference was observed in
$A$ among the maize hybrids (Table 7), which suggests that the highest $\Delta C$ of the $2 \mathrm{~B} 707 \mathrm{Bt}$ maize may not reflect in growth gains for that hybrid in relation to the others.

Water deficit reduced $E, g_{\mathrm{s}} A, \mathrm{SPAD}, F_{v}$ $F_{m}, F_{v} / F_{o}$ and $q P$ of maize plants, but increased their $F_{o}$ and $F_{o} / F_{m}$ (Table 6). The most common response to water deficit is the stomatal closure (decrease in $g_{s}$ ), which consequently reduces the plant photosynthetic rate $(A)$, since it limits the entry of $\mathrm{CO}_{2}$ in the cell (Jain et al., 2019). Under such condition, the beginning of photoinhibition processes may also take place (Gururani et al., 2015). Decrease of $F_{v} / F_{m}$ ratio and increase in $F_{o}$ of maize cultivated in soil with water deficit (Table 6) suggest that there might be destruction of the thylakoid membrane structure of those plants (Araújo \& Deminicis, 2009). However, it should be noted that the $F_{v} /$

Table 6. Transpiration $(E)$, stomatal conductance $\left(g_{s}\right)$, photosynthetic rate $(A)$, chlorophyll content (SPAD), minimal fluorescence $\left(F_{o}\right)$, maximum quantum yield $\left(F_{v} / F_{m}\right)$, basal quantum yield of nonphotochemical processes in the PSII $\left(F_{o} / F_{m}\right)$, maximum efficiency of the photochemical process in the PSII $\left(F_{v} / F_{o}\right)$, and photochemical quenching coefficient $(q P)$ in $B t$ and non- $B t$ maize hybrids cultivated in soil with moisture content at 60 and $100 \%$ of the field capacity (FC), 41 days after emergence.

\begin{tabular}{cccccccccc}
\hline $\begin{array}{c}\text { Water } \\
\text { availability }\end{array}$ & $E$ & $g_{\mathrm{s}}$ & $A$ & $\mathrm{SPAD}$ & $F_{o}$ & $F_{v} F_{m}$ & $F_{o} / F_{m}$ & $F_{v} F_{o}$ & $q P$ \\
$60 \% \mathrm{FC}$ & $2.69 \mathrm{~b}$ & $0.070 \mathrm{~b}$ & $9.983 \mathrm{~b}$ & $39.02 \mathrm{~b}$ & $767.1 \mathrm{a}$ & $0.762 \mathrm{~b}$ & $0.242 \mathrm{a}$ & $3.164 \mathrm{~b}$ & $0.777 \mathrm{~b}$ \\
$100 \% \mathrm{FC}$ & $5.306 \mathrm{a}$ & $0.177 \mathrm{a}$ & $21.442 \mathrm{a}$ & $42.33 \mathrm{a}$ & $723.0 \mathrm{~b}$ & $0.786 \mathrm{a}$ & $0.223 \mathrm{~b}$ & $3.525 \mathrm{a}$ & $0.823 \mathrm{a}$ \\
\hline
\end{tabular}

* Means followed by the same lowercase letter in the columns do not differ from one another at $5 \%$ probability as per Tukey's test. 
Table 7. Summary of the analysis of variance for minimal fluorescence $\left(F_{O}\right)$, maximal fluorescence of dark-adapted sample $(F m)$, variable fluorescence $(F v)$, maximum photochemical efficiency of the photosystem II (PSII) $\left(F_{v} / F_{m}\right)$, basal quantum yield of non-photochemical processes in the PSII $\left(F_{o} / F_{m}\right)$, maximum efficiency of the photochemical process in the PSII $\left(F_{v} F_{o}\right)$, photochemical quenching $(q P)$, non-photochemical quenching $(N P Q)$, transpiration $(E)$, stomatal conductance $(g s)$, photosynthetic rate $(A), \mathrm{CO}_{2}$ consumed $(\triangle C)$, and chlorophyll content (SPAD) in $B t$ and non- $B t$ maize hybrids cultivated in soil with moisture content at 60 and $100 \%$ of the field capacity (FC), 41 days after emergence.

\begin{tabular}{|c|c|c|c|c|c|c|c|c|}
\hline Source of Variation & $\mathrm{DF}$ & $F_{O}$ & $F m$ & $F v$ & $F v / F m$ & $F_{\delta} / F m$ & $F v / F_{O}$ & $q P$ \\
\hline Block & 4 & 5544.48 & 73985.39 & 53305.4 & 0.00032 & 0.00032 & 0.102 & 0.6421 \\
\hline Hybrid (H) & 2 & $3091.42^{\mathrm{NS}}$ & $90612.19^{\mathrm{NS}}$ & $47337.4^{\mathrm{NS}}$ & $0.00022^{\mathrm{NS}}$ & $0.00022^{\mathrm{NS}}$ & $0.052^{\mathrm{NS}}$ & $0.0107^{\mathrm{NS}}$ \\
\hline Gene $(\mathrm{G})$ & 1 & $2781.20^{\mathrm{NS}}$ & $683893.9^{* *}$ & $540977.6^{*}$ & $0.00074^{\mathrm{NS}}$ & $0.00074^{\mathrm{NS}}$ & $0.334^{\mathrm{NS}}$ & $2.0609^{\mathrm{NS}}$ \\
\hline Water deficit (D) & 1 & $29282.50 * *$ & $21347.63^{\mathrm{NS}}$ & $126707.1^{\mathrm{NS}}$ & $0.00056^{* *}$ & $0.00556^{* *}$ & $1.956^{* *}$ & $4.2135^{*}$ \\
\hline $\mathrm{H}^{*} \mathrm{G}$ & 2 & $344.92^{\mathrm{NS}}$ & $149418.2^{\mathrm{NS}}$ & $191652.7^{\mathrm{NS}}$ & $0.00215^{*}$ & $0.00215^{*}$ & $0.616^{*}$ & $2.2944^{\mathrm{NS}}$ \\
\hline $\mathrm{H}^{*} \mathrm{D}$ & 2 & $3764.82^{\mathrm{NS}}$ & $325643.9^{\mathrm{NS}}$ & $288730.8^{*}$ & $0.00114^{\mathrm{NS}}$ & $0.00115^{\mathrm{NS}}$ & $0.329^{\mathrm{NS}}$ & $8.6136^{\mathrm{NS}}$ \\
\hline$G^{*} \mathrm{D}$ & 1 & $3397.53^{\mathrm{NS}}$ & $27831.83^{\mathrm{NS}}$ & $21688.5^{\mathrm{NS}}$ & $0.00003^{\mathrm{NS}}$ & $0.00004^{\mathrm{NS}}$ & $0.006^{\mathrm{NS}}$ & $5.0784^{\mathrm{NS}}$ \\
\hline $\mathrm{H}^{*} \mathrm{G}^{*} \mathrm{D}$ & 2 & $80.36^{\mathrm{NS}}$ & $258803.6^{\mathrm{NS}}$ & $250535.7^{*}$ & $0.00120^{\mathrm{NS}}$ & $0.00119^{\mathrm{NS}}$ & $0.453^{\mathrm{NS}}$ & $3.3362^{\mathrm{NS}}$ \\
\hline Residue & 44 & 4039.852 & 88133.48 & 75782.9 & 0.00065 & 0.00065 & 0.183 & 7.839 \\
\hline CV (\%) & & 8.53 & 9.16 & 11.05 & 3.33 & 10.97 & 12.8 & 12.8 \\
\hline Source of Variation & $\mathrm{DF}$ & NPQ & $E$ & $g s$ & $A$ & $C$ & SPAD & \\
\hline Block & 4 & 0.001 & 16.616 & 0.054 & 26.063 & 330.415 & 11.396 & \\
\hline Hybrid (H) & 2 & $0.257^{\mathrm{NS}}$ & $5.854^{\mathrm{NS}}$ & $0.005^{\mathrm{NS}}$ & $8.902^{\mathrm{NS}}$ & $178.767^{\mathrm{NS}}$ & $241.218^{* *}$ & \\
\hline Gene $(\mathrm{G})$ & 1 & $0.003^{\mathrm{NS}}$ & $0.086^{\mathrm{NS}}$ & $0.00003^{\mathrm{NS}}$ & $10.827^{\mathrm{NS}}$ & $137.765^{\mathrm{NS}}$ & $36.192^{\mathrm{NS}}$ & \\
\hline Water deficit (D) & 1 & $0.005^{\mathrm{NS}}$ & $102.621 * *$ & $0.172 * *$ & $37.500^{\mathrm{NS}}$ & $105.143^{\mathrm{NS}}$ & $164.672 * *$ & \\
\hline $\mathrm{H}^{*} \mathrm{G}$ & 2 & $0.139^{\mathrm{NS}}$ & $2.347^{\mathrm{NS}}$ & $0.0003^{\mathrm{NS}}$ & $5.088^{\mathrm{NS}}$ & $189.925^{*}$ & $27.640^{\mathrm{NS}}$ & \\
\hline $\mathrm{H}^{*} \mathrm{D}$ & 2 & $0.070^{\mathrm{NS}}$ & $1.054^{\mathrm{NS}}$ & $0.0003^{\mathrm{NS}}$ & $5.780^{\mathrm{NS}}$ & $48.101^{\mathrm{NS}}$ & $4.630^{\mathrm{NS}}$ & \\
\hline $\mathrm{G}^{*} \mathrm{D}$ & 1 & $0.046^{\mathrm{NS}}$ & $4.941^{\mathrm{NS}}$ & $0.005^{\mathrm{NS}}$ & $38.08^{\mathrm{NS}}$ & $113.682^{\mathrm{NS}}$ & $100.880 *$ & \\
\hline $\mathrm{H}^{*} \mathrm{G}^{*} \mathrm{D}$ & 2 & $0.301^{*}$ & $7.604^{\mathrm{NS}}$ & $0.0007^{\mathrm{NS}}$ & $34.73^{\mathrm{NS}}$ & $725.639^{\mathrm{NS}}$ & $10.152^{\mathrm{NS}}$ & \\
\hline Residue & 44 & 0.091 & 4.673 & 0.007 & 110.04 & 563.796 & 18.621 & \\
\hline CV (\%) & & 24.96 & 54.056 & 71.279 & 29.96 & 29.96 & 10.609 & \\
\hline
\end{tabular}

"significant at 5\%, ${ }^{* *}$ significant at $1 \%$, and ${ }^{\mathrm{NS}}$ not significant according to F-test. 
$F_{m}$ values of maize were over 0.75 , even under water stress. Therefore, the efficiency of light energy conversion in the plant probably has not been compromised (Abid et al., 2017; Quiles, 2005). It is also important to point out that leaf roll was observed in maize hybrids under water stress, which may indicate adaptations to reduce the radiation interception and transpiration area. This leaf movement creates a microclimate and reduces the transpiration surface, thus lowering water loss by the plant (Souza et al., 2013) and lessening the damages to the plant photosynthetic apparatus.

Reduction of $F_{v} / F_{m}$ in maize plants cultivated in soil at $60 \%$ of FC (Table 6) is probably due to a photochemical adjustment as a result of chlorophyll content decrease in maize leaves (Table 6), and the consequent loss in the light-harvesting capacity of the plants. It is known that the chlorophyll molecule is constantly synthesized and destroyed in the presence of light (photo-oxidation), though the decomposition speed is faster under high light radiation intensity, with the balance being established at a lower concentration (Taiz \& Zeiger, 2013).

Water deficit during the vegetative period reduces maize growth, mainly in the leaf area, and accumulation of dry matter (Jain et al., 2019). In this research, it was observed that water stress during the V5 and V9 vegetative stages reduces the photosynthetic potential of maize (lower stomatal conductance, transpiration, photosynthetic rate, chlorophyll content, etc.), which may compromise the productive output of maize. Besides, the sensitivity to water stress varies depending on the maize hybrid and the presence of the $B t$ gene. When cultivated in soil under water deficit condition, the transgenic hybrids presented, mainly, lower chlorophyll content and maximal fluorescence in relation to the conventional versions. Therefore, it is possible that the $B t$ maize will present lower productive performance in comparison with the conventional maize, under water stress conditions.

\section{Conclusions}

The presence of the $B t$ gene increases the sensitivity of maize hybrids to soil water deficit.

The physiological response of maize to water stress depends on the hybrid and the presence of the $B t$ gene.

Water stress during the vegetative stage of maize reduces maximum quantum yield of the photosystem II, stomatal conductance, transpiration, photosynthetic rate and chlorophyll content of the plant.

\section{Acknowledgments}

This work was funded by the Brazilian National Council for Scientific and Technological Development $(\mathrm{CNPq})$, and partly funded by the Coordination for the Improvement of Higher Education Personnel (CAPES) - Financial Code 001, and the Research Support Foundation of the 
State of Minas Gerais (FAPEMIG).

This work was funded by the Instituto Federal Goiano and Conselho Nacional de Desenvolvimento Científico e Tecnológico (CNPq) and in part by the Coordenação de Aperfeiçoamento de Pessoal de Nível Superior Brasil (CAPES) - Finance Code 001 and Fundação de Amparo à Pesquisa do Estado de Minas Gerais (FAPEMIG).

\section{References}

ABID, G.; M'HAMDI, M.; MINGEOT, D.; AOUIDA, M.; AROUA, I.; MUHOVSKI, Y.; SASSI, K.; SOUISSI, F.; MANNAI, K.; JEBARA, M. Effect of drought stress on chlorophyll fluorescence, antioxidant enzyme activities and gene expression patterns in faba bean (Vicia faba L.). Archives of Agronomy and Soil Science, v. 63, n. 4, p. 536-552, 2017. DOI: 10.1080/03650340.2016.1224857.

ARAÚJO, S. A. C.; DEMINICIS, B. B. Fotoinibição da fotossíntese. Revista Brasileira de Biociências, v. 7, n. 4, p. 463-472, 2009.

ASPIAZÚ, I.; SEDIYAMA, T.; RIBEIRO JR., J. I.; SILVA, A. A.; CONCENÇO, G.; FERREIRA, E. A.; GALON, L.; SILVA, A. F.; BORGES, E. T.; ARAÚJO, W. F. Photosynthetic activity of cassava plants under weed competition. Planta Daninha, v. 28, n. spe, p. 963-968, 2010. DOI: $10.1590 / \mathrm{S} 0100-83582010000500004$.
ATANASSOVA, A.; KEIPER, F. Plant breeding innovation: A global regulatory perspective. Cereal Chemistry, v. 95, n. 1, p. 8-16, 2018. DOI: 10.1002/cche.10021.

BAGHEL, L., KATARIA, S., GURUPRASAD, K. N. Effect of static magnetic field pretreatment on growth, photosynthetic performance and yield of soybean under water stress. Photosynthetica, v. 56, p. n. 2, 718-730, 2018. DOI: 10.1007/ s11099-017-0722-3.

BAKER, N. R. Chlorophyll fluorescence: a probe of photosynthesis in vivo. Annual Review of Plant Biology, v. 59, n. 1, p. 89-113, 2008. DOI: 10.1146/annurev.arplant.59.032607.092759.

BALIEIRO NETO, G.; CIVIDANES, T. M. S.; BRANCO, R. B.; FELIX, M. R. F.; REI, F. M. C. T.; NOGUEIRA, J. R. Quantificação da proteína Cry1 Ab em folhas, caules e grãos de dois híbridos de milho Bt e controle das pragas Spodoptera frugiperda e Helicoverpa zea. Boletim de Indústria Animal, v. 70, n. 1, p. 59-66, 2013. DOI: 10.17523/bia.v70n1p59.

BANKS, J. M. Continuous excitation chlorophyll fluorescence parameters: a review for practitioners. Tree Physiology, v. 37, n. 8, p. 1128-1136, 2017. DOI: 10.1093/treephys/ tpx059.

BERTAMINI, M.; NEDUNCHEZHIAN, N. Photoinhibition of photosynthesis in mature and 
young leaves of grapevine (Vitis vinifera L.). Plant Science, v. 164, n. 4, p. 635-644, 2003. DOI: 10.1016/S0168-9452(03)00018-9.

BROOKES, G.; BARFOOT, P. Farm income and production impacts of using GM crop technology 1996-2016.GMCrops\& Food, v.9, n. 2,p. 59-89, 2018. DOI: 10.1080/21645698.2018.1464866.

CAIRES, A. R. L.; SCHERER, M. D.; SANTOS, T. S. B.; PONTIM, B. C. A.; GAVASSONI, W. L.; OLIVEIRA, S. L. Water stress response of conventional and transgenic soybean plants monitored by chlorophyll a fluorescence. Journal of fluorescence, v. 20 , n. 3, p. 645-9, 2010. DOI: 10.1007/s10895-009-0594-4.

CASSANA, F. F.; BRAGA, E. J. B.; BACARIN, M. A.; FAlQUeto, A. R.; PETERS, J. A. Atividade fotoquímica máxima do fotossistema II em plantas de batata-doce cultivadas in vitro e aclimatizadas. Current Agricultural Science and Technology, v. 14, n. 4, p. 46-51, 2013.

CHEN, D.; YE, G.; YANG, C.; CHEN, Y.; WU, Y. Effect after introducing Bacillus thuringiensis gene on nitrogen metabolism in cotton. Field Crops Research, v. 87, n. 2-3, p. 235-244, 2004. DOI: 10.1016/j.fcr.2003.11.001.

GURURANI, M. A.; VENKATESH， J.; TRAN, L. S. P. Regulation of photosynthesis during abiotic stress-induced photoinhibition. Molecular Plant, v. 8, n. 9, p. 1304-1320, 2015.
DOI: 10.1016/j.molp.2015.05.005.

JJAIN， M.; KATARIA， S.; HIRVE， M.; PRAJAPATI, R. Water deficit stress effects and responses in maize. In: HASANUZZAMAN, M.; HAKEEM, K. R.; NAHAR, K.; ALHARBY, H. Plant abiotic stress tolerance. New York: Springer International Publishing, 2019. p. 129151. DOI: 10.1007/978-3-030-06118-0_5.

JAMIESON, M. A.; TROWBRIDGE, A. M.; RAFFA, K. F.; LINDROTH, R. L. Consequences of climate warming and altered precipitation patterns for plant-insect and multitrophic interactions. Plant physiology, v. 160, n. 4, p. 1719-27, 2012. DOI: 10.1104/pp.112.206524.

JU, Y.; YUE, X.; ZHAO, X.; ZHAO, H.; FANG, Y. Physiological, micro-morphological and metabolomic analysis of grapevine (Vitis vinifera L.) leaf of plants under water stress. Plant Physiology and Biochemistry, v. 130, p. 501510, 2018. DOI: 10.1016/j.plaphy.2018.07.036.

KAMTHAN, A.; CHAUDHURI, A.; KAMTHAN, M.; DATTA, A. Genetically modified (GM) crops: milestones and new advances in crop improvement. Theoretical and Applied Genetics, v. 129, n. 9, p. 1639-1655, 2016. DOI: 10.1007/s00122-016-2747-6.

KARUPPANAPANDIAN, T.; MOON, J. C.; KIM, C.; MANOHARAN, K.; KIM, W. Reactive oxygen species in plants: their generation, signal 
transduction, and scavenging mechanisms. Australian Journal of Crop Science, v. 5, n. 6, p. 709-725, 2011.

\section{LATHAM, J. R.; WILSON, A. K.;} STEINBRECHER, R. A. The mutational consequences of plant transformation. Journal of biomedicine \& biotechnology, v. 2006, n. 2, p. 25376, 2006. DOI: 10.1155/JBB/2006/25376.

MATOS, C. C.; SILVA, C. T.; CUNHA, P. T.; GANDINI, E. M. M.; SILVA, D. V.; BARBOSA, E. A.; SANTOS, J. B.; FERREIRA, E. A. Nicandra physalodes growth at different concentrations of N, P and K. Semina: Ciências Agrárias, v. 36, n. 3, p. 1307-1316, 2015. DOI: 10.5433/1679-0359.2015v36n3p1307.

MISHRA, A. N. Chlorophyll Fluorescence: A Practical Approach to Study Ecophysiology of Green Plants. In: SÁNCHEZ-MOREIRAS, A. M.; REIGOSA, M. J. Advances in Plant Ecophysiology Techniques. New York: Springer International Publishing. 2018, p. 77-97. DOI: 10.1007/978-3-319-93233-0_5.

MOLINARI, H. B. C.; MARUR, C. J.; DAROS, E.; CAMPOS, M. K. F.; CARVALHO, J. F. R. P.; FILHO, J. C. B.; PEREIRA, L. F. P.; VIEIRA, L. G. E. Evaluation of the stress-inducible production of proline in transgenic sugarcane (Saccharum spp.): osmotic adjustment, chlorophyll fluorescence and oxidative stress. Physiologia Plantarum, v. 130, n. 2, p. 218-229,
2007. DOI: 10.1111/j.1399-3054.2007.00909.x.

MOREIRA, L. R.; ERVILHA, J. D. C.; COUTINHO, P. H.; VIDIGAL, J. G.; OGLIARI, J.; MIRANDA, G. V.; PEREIRA, L. F. Caracterização fisiológica de sorgo sacarino em diferentes intensidades de irrigação. Revista Vértices, v. 15, n. 2, p. 39-48, 2013. DOI: 10.19180/1809-2667.20130017.

MURCHIE, E. H., LAWSON, T. Chlorophyll fluorescence analysis: a guide to good practice and understanding some new applications. Journal of Experimental Botany, v. 64, n. 13, p. 3983-3998, 2013. DOI: 10.1093/jxb/ert208.

NUCCIO, M. L.; PAUL, M.; BATE, N. J.; COHN, J.; CUTLER, S. R. Where are the drought tolerant crops? An assessment of more than two decades of plant biotechnology effort in crop improvement. Plant Science, v. 273, p. 110-119, 2018. DOI: 10.1016/j.plantsci.2018.01.020.

PELLEGRINO, E.; BEDINI, S.; NUTI, M.; ERCOLI, L. Impact of genetically engineered maize on agronomic, environmental and toxicological traits: a meta-analysis of 21 years of field data. Scientific Reports, v. 8, n. 1, 3113, 2018. DOI: 10.1038/s41598-018-21284-2.

QUILES, M. J. Photoinhibition of photosystems I and II using chlorophyll fluorescence measurements. Journal of Biological Education, v. 39, n. 3, p. 136-138, 2005. DOI: 
10.1080/00219266.2005.9655981.

RASCOJR,E.;MANGUBAT,J.R.;BURGONIO, A. B.; LOGRONO, M. L.; VILLEGAS, V. N.; FERNANDEZ, E. C. Agronomic performance and asiatic corn borer resistance of tropical converted transgenic corn hybrids containing the truncated Cry1A(b) gene (Bt-11) in Davao city, Philippines. Crop Protection Newsletter, v. 35, n. 1, p. 1-15, 2010.

ROHÁČEK, K. Chlorophyll fluorescence parameters: the definitions, photosynthetic meaning, and mutual relationships. Photosynthetica, v.40, n.1, p.13-29, 2002. DOI: 10.1023/A:1020125719386.

ROHÁČEK, K.; BARTÁK, M. Technique of the modulated chlorophyll fluorescence: Basic concepts, useful parameters, and some applications. Photosynthetica, v. 37, n. 3, p. 339363, 1999. DOI: 10.1023/A:1007172424619.

ROLLI, E.; MARASCO, R.; VIGANI, G.; ETTOUMI, B.; MAPELLI, F.; DEANGELIS, M. L.; GANDOLFI, C.; CASATI, E.; PREVITALI, F.; GERBINO, R.; PIEROTTI CEI, F.; BORIN, S.; SORLINI, C.; ZOCCHI, G.; DAFFONCHIO, D. Improved plant resistance to drought is promoted by the root-associated microbiome as a water stress-dependent trait. Environmental Microbiology, v. 17, n. 2, p. 316-331, 2015. DOI: $10.1111 / 1462-2920.12439$.
ROSA, D. B. C. J.; SCALON, S. P. Q.; CREMON, T.; DRESCH, D. M. Gas exchanges and antioxidant activity in Copaifera langsdorffii Desf. seedlings after flooding. American Journal of Plant Sciences, v. 09, n. 05, p. 979-994, 2018. DOI: 10.4236/ajps.2018.95075.

RUBAN, A. V.; JOHNSON, M. P.; DUFFY, C. D. P. The photoprotective molecular switch in the photosystem II antenna. Biochimica et Biophysica Acta, v. 1817, n. 1, 167-81, 2012. DOI: 10.1016/j.bbabio.2011.04.007.

SATO, R.; KONO, M.; HARADA, K.; OHTA, H.; TAKAICHI, S.; MASUDA, S. FLUCTUATINGLIGHT-ACCLIMATION PROTEIN1, Conserved in Oxygenic Phototrophs, Regulates $\mathrm{H}+$ Homeostasis and Non-Photochemical Quenching in Chloroplasts. Plant Cell Physiology, v. 58, n. 10, p. 1622-1630, 2017. DOI: $10.1093 / \mathrm{pcp} / \mathrm{pcx} 110$

SOUZA, T. C.; CASTRO, E. M.; MAGALHÃES, P. C.; LINO, L. O.; ALVES, E. T.; ALBUQUERQUE, P. E. P. Morphophysiology, morphoanatomy, and grain yield under field conditions for two maize hybrids with contrasting response to drought stress. Acta Physiologiae Plantarum, v. 35, n. 11, p. 3201-3211, 2013. DOI: 10.1007/s11738-013-1355-1.

TAIZ, L.; ZEIGER, E. Fisiologia vegetal. 5. ed. Porto Alegre: Artmed, 2013. 954p. 
TAN; X.; FAN; Z.; KUANG; J.; LU; W.; XING, Y.; QIN, Z.; FENG, M.; LI, A.; ZHANG, REITER; R.J.; LAKSHMANAN; P.; SU; X.; L.; WANG, Y.; DONG, X.; ZHANG, Y.; TAN, ZHOU; J.; CHEN; J.; SHAN; W. Melatonin S.; SHI, W. The impact of Bt maize expressing delays leaf senescence of Chinese flowering the Cry1Ac protein on non-target arthropods. cabbage by suppressing ABFs-mediated abscisic Environmental Science and Pollution acid biosynthesis and chlorophyll degradation. Research, v. 26, n. 6, p. 5814-5819, 2019. DOI: Journal of Pineal Research, v. 67, p. e12570, 10.1007/s11356-018-4025-4. 2019. DOI: $10.1111 /$ jpi.12570. 